\title{
TINJAUAN YURIDIS PENYALAHGUNAAN PERJANJIAN PEMBERI LISENSI MEREK BERDASARKAN UNDANG-UNDANG NOMOR 15 TAHUN 2001 TENTANG MEREK
}

Oleh :

\author{
Ferdian, SH, MH
}

Dosen Tidak Tetap Fakultas Hukum Universitas Dirgantara Marsekal Suryadarma

\begin{abstract}
Abstrak :
Merek merupakan hal yang sangat penting dalam dunia berniagaan, sebab merek sebagai tanda pengenal barang atau jasa sebuah perusahaan, sehingga konsumen dapat mengenal kualitas barang atau jasa dilihat dari merek dagang tersebut. Lisensi merek hendaklah mengandung itikad baik pada saat membuat perjanjian lisensi. Pengalihan merek, seseorang atau badan hukum dapat menggunakan merek tertentu dengan melalui cara lisensi merek. Ketentuan-ketentuan tentang kontrak lisensi merek dalam Undang-Undang Nomor 15 Tahun 2001 tentang Merek terdapat dalam ketentuan Pasal 43 sampai dengan Pasal 49. Administrasi merek mengurus masalah yang berkaitan dengan tata cara, dan penatausahaan merek. Penyelenggaraan administrasi oleh Direktorat Jenderal Hak Atas Kekayaan Intelektual. Faktor penyebab terjadinya sengketa dalam perjanjian lisensi merek dengan cara-cara adalah sebagai berikut : a. praktik peniruan merek dagang, b. praktik pemalsuan merek dagang, $c$. Perbuatan-perbuatan yang dapat mengacaukan publik berkenaan dengan sifat dan asal usul merek. Penyelesaian Sengketa dalam ruang lingkup hukum keperdataan khususnya Perjanjian Lisensi Merek dapat diselesaikan secara non litigasi yaitu penyelesaian sengketa alternatif diluar sistem dan hukum acara yang berlaku pada badan peradilan. Alternatif penyelesaian sengketa dapat diselesaikan dengan konsultasi, negosiasi, mediasi, konsiliasi, atau penilaian ahli serta melalui arbitrase. Kemudian dapat secara litigasi diselesaikan melalui badan pengadilan dengan mempergunakan hukum acara perdata yang berlaku di Indonesia sebagaimana diatur di dalam Undang-Undang Nomor 15 Tahun 2001 dapat diajukan kepada Pengadilan Niaga maupun Pengadilan Negeri (diatur dalam Pasal 90 UndangUndang Nomor 15 Tahun 2001).
\end{abstract}

Kata Kunci : Perjanjian Lisensi Merek

\section{PENDAHULUAN}

\section{A. Latar Belakang Masalahan}

Dalam pertumbuhan ekonomi saat ini di Indonesia merek merupakan salah satu wujud karya intelektual, memiliki peranan penting bagi kelancaran dan peningkatan perdagangan dan jasa. Dalam praktek, pemilikan dan penggunaan merek, sering menimbulkan persaingan bahkan permasalahan di kalangan para pedagang dalam kaitan dengan merek perusahaan dan merek perniagaan. Merek merupakan tanda 
pengenal asal barang dan jasa, sekaligus mempunyai fungsi menghubungkan barang dan jasa yang bersangkutan dengan produsennya, maka hal itu menggambarkan jaminan kepribadian (individuality) dan reputasi barang dan jasa hasil usahanya tersebut sewaktu diperdagangkan. Merek selain memberikan jaminan nilai atau kualitas dari barang dan jasa yang bersangkutan, juga memberikan perlindungan dan jaminan mutu barang kepada konsumen.

\section{Undang-undang memberikan pengertian merek sebagaimana ditentukan dalam Pasal 1 angka 1 Undang-Undang Nomor 15 Tahun 2001 tentang Merek sebagai berikut :}

"Merek adalah tanda yang berupa gambar, nama, kata, huruf-huruf, angka-angka, susunan warna, atau kombinasi dari unsur-unsur tersebut yang memiliki daya pembeda dan digunakan dalam kegiatan perdagangan barang atau jasa". ${ }^{1}$

Merek merupakan hal yang sangat penting dalam dunia perniagaan, sebab merek sebagai tanda pengenal barang atau jasa sebuah perusahaan, sehingga konsumen dapat mengenal kualitas barang atau jasa di lihat dari merek dagang tersebut, karena begitu pentingnya merek maka banyak kalangan bisnis yang telah melakukan penyimpanganpenyimpangan yaitu dengan cara melakukan penjiplakan terhadap merek-merek yang sudah terkenal di masyarakat demi memperoleh keuntungan yang sebesar-besarnya,

${ }^{1}$ Undang-Undang Republik Indonesia Nomor 15 Tahun 2001 tentang Merek, Pasal 1 angka 1. seperti halnya pemilik logo yang sah sehinggga dapat menyebabkan pencemaran nama baik, dan dapat merugikan pemilik merek tersebut.

Ketentuan mengenai perjanjian lisensi termuat dalam ketenetuan Pasal 43 Undang-Undang Nomor 15 Tahun 2001 tentang Merek yang merumuskan bahwa :

(1) Pemilik Merek terdaftar berhak memberikan Lisensi kepada pihak lain dengan perjanjian bahwa penerima Lisensi akan menggunakan Merek tersebut untuk sebagian atau seluruh jenis barang atau jasa.

(2) Perjanjian Lisensi berlaku di seluruh wilayah Negara Republik Indonesia, kecuali bila diperjanjikan lain, untuk jangka waktu yang tidak lebih lama dari jangka waktu perlindungan Merek terdaftar yang bersangkutan.

(3) Perjanjian Lisensi wajib dimohonkan pencatatannya pada Direktorat Jenderal dengan dikenai biaya dan akibat hukum dari pencatatan perjanjian Lisensi berlaku terhadap pihak-pihak yang bersangkutan dan terhadap pihak ketiga.

(4) Perjanjian Lisensi sebagaimana dimaksud pada ayat (3) dicatat oleh Direktorat Jenderal dalam Daftar Umum Merek dan diumumkan dalam Berita Resmi Merek. $^{2}$

Menurut OK. Saidin menyatakan bahwa :

\footnotetext{
${ }^{2}$ Ibid., Pasal 43.
} 
"Pemberian lisensi kepada pihak lain, harus dituangkan dalam bentuk perjanjian lisensi, dan setiap pelepasan hak dengan perjanjian (termasuk perjanjian lisensi) harus dituangkan dalam bentuk akta perjanjian". ${ }^{3}$

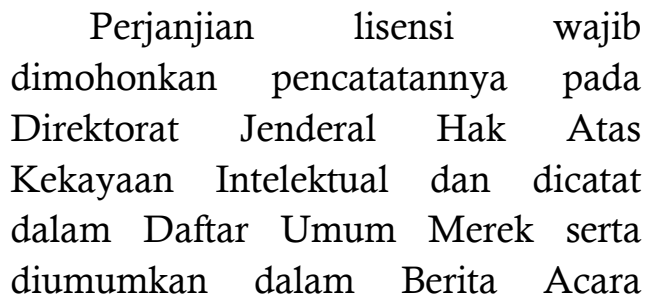
Resmi Merek. Lisensi merek hendaklah mengandung itikad baik pada saat membuat perjanjian lisensi. Hal ini dimaksudkan karena perjanjian lisensi bukanlah suatu perjanjian pengalihan hak namun merupakan pemberian hak yang diberikan dari pemilik merek kepada pihak lain dengan jangka waktu tertentu dan dengan syarat tertentu.

Pemohon yang beritikad baik adalah pemohon yang mendaftarkan mereknya secara layak dan jujur tanpa ada niat apa pun untuk membonceng, meniru atau menjiplak ketenaran merek pihak lain demi kepentingan usahanya yang berakibat kerugian kepada pihak lain itu atau menimbulkan kondisi persaingan curang, mengecoh atau menyesatkan konsumen sedangkan permohonan yang tidak beritikad baik harus ditolak. Pemohon yang beritikad tidak baik adalah perusahaan :

"Contohnya : Merek Dagang A yang sudah dikenal masyarakat secara umum sejak bertahun-tahun, ditiru demikian rupa sehingga memiliki

${ }^{3}$ Ok. Saidin, Aspek Hukum Hak Kekayaan Intelektual (Intellectual Property Rights), Jakarta : RajaGrafindo Persada, 2013, hal. 384. persamaan pada pokoknya atau keseluruhannya dengan merek dagang A tersebut". ${ }^{4}$

Dalam contoh itu sudah terjadi itikad tidak baik dari peniru karena setidak-tidaknya patut diketahui unsur kesengajaannya dalam meniru merek dagang orang lain yang telah dikenal tersebut. Begitu banyaknya penyimpangan-penyimpangan yang terjadi dalam praktek perniagaan dan perkembangan keadaan, untuk itu perlunya pengelolaan administrasi yang baik. Administrasi merek mengurus masalah yang berkaitan dengan tata cara, dan penatausahaan merek. Fungsinya melaksanakan undang-undang dengan menjalankan kehendak dan perintah undangundang, secara nyata, kasual, dan individual. Produknya berupa penetapan, pelayanan kepada masyarakat, penyelenggaraan pekerjaan dan kegiatan-kegiatan nyata.

Sebagai pelaksana yang menyelenggarakan administrasi (administrator) adalah pemerintah yang dilaksanakan oleh Direktorat Jenderal Hak Atas Kekayaan Intelektual. Direktorat Jenderal Hak Atas Kekayaan Intelektual akan bersikap melayani (service) dan menangani (handling) orang-orang perorangan (individu) beserta kasus-kasus merek secara kasuistis. Bentuk dari pelayanan administrator berupa melayani permohonan pendaftaran merek, pemeriksaan merek, dan menetapkan merek, juga menyelenggarakan bersifat nasional,

${ }^{4}$ Pipin Syarifin, Dedah Jubaedah, Peraturan Hak Kekayaan Intelektual di Indonesia, Bandung : Putaka Bani Quraisy, 2004, hal. 171. 
yang mampu menyediakan informasi tentang merek seluas mungkin kepada masyarakat.

Masalah yang berkaitan dengan administrasi diatur dengan menegaskan hal-hal yang dilakukan oleh Direktorat Jenderal dalam menangani pemeriksaan adminsitrasi, dan juga ketentuan yang berkaitan dengan kewajiban orang yang mengajukan pendaftaran merek, baik dalam pemenuhan kelengkapan atau melakukan perbaikan apabila syaratsyarat administrasinya masih mengandung kekurangan.

Apabila terjadinya pelanggaran terhadap hak merek motivasinya adalah untuk mendapatkan keuntungan secara mudah, dengan mencoba, meniru, atau memalsukan merek-merek yang sudah terkenal di masyarakat. Tindakan tersebut dapat merugikan masyarakat, baik itu pihak produsen maupun pihak konsumennya, selain itu pula negara pun dirugikan, untuk itu perlunya penegakan hukum dalam menyikapi permasalahan-permasalahan tersebut yang berlandasakan pada UndangUndang Nomor 15 Tahun 2001 tentang Merek, yang meliputi Merek Dagang dan Merek Jasa.

Berdasarkan uraian tersebut di atas penulis tertarik untuk membahas permasalahan mengenai merek dalam tesis ini dengan judul: "Tinjauan Yuridis Penyalahgunaan Perjanjian Pemberi Lisensi Merek Berdasarkan Undang-Undang Nomor 15 Tahun 2001 Tentang Merek".

\section{B. Rumusan Masalah}

Rumusan masalah yang akan dibahas adalah sebagai berikut :

1. Bagaimana dasar pelaksanaan pengelolaan administrasi merek?

2. Bagaimana faktor penyebab terjadinya sengketa dalam perjanjian lisensi merek?

3. Bagaimana upaya penyelesaian perselisihan terhadap pelanggaran merek?

\section{Tujuan Penelitian}

Tujuan penelitian ini adalah sebagai berikut :

1. Untuk memberikan gambaran tentang dasar pelaksanaan pengelolaan administrasi merek

2. Untuk memberikan gambaran faktor yang sering terjadi dalam sengketa perjanjian lisensi merek.

3. Untuk memberikan gambaran mengenai upaya penyelesaian perselisihan terhadap pelanggaran merek.

\section{HAK ATAS KEKAYAAN INTELEKTUAL DAN MEREK}

\section{A. Hak Atas Kekayaan Intelektual}

\section{Pengertian Hak Atas Kekayaan Intelektual}

Istilah hak atas kekayaan intelektual merupakan terjemahan dari istilah Intellectual Property Rights (Bahasa Inggris) dalam sistem hukum Anglo Saxon. Sedangkan istilah hak atas milik 
intelektual merupakan terjemahan dari istilah intellectuele eigendomsrecht (Bahasa Belanda) dalam sistem hukum Kontinental.

Menurut sistem hukum perdata, hukum mengenai harta kekayaan meliputi hukum kebendaan dan hukum perikatan. Intelektual Property Rights merupakan kebendaan immateril yang juga menjadi objek hak milik sebagaimana diatur dalam hukum kebendaan.

Menurut Ahmad M. Ramli, mengatakan bahwa :

"kata milik atau kepemilikan lebih tepat digunakan dari pada kata kekayaan karena pengertian hak milik memiliki ruang lingkup lebih khusus dibandingkan dengan istilah kekayaan menurut sistem hukum kita, hukum harta kekayaan itu meliputi hukum kebendaan dan hukum perikatan". Intellectual Property Rights merupakan kebendaan immaterial yang juga menjadi objek hak milik sebagaimana diatur dalam hukum kebendaan. Karena itu lebih tepat kalau kita menggunakan istilah Hak atas Kepemilikan Intelektual (HaKI) dari pada istilah Hak atas Kekayaan Intelektul". 5

Menurut Subekti menjelaskan bahwa:

"secara garis besarnya hukum harta kekayaan ini meliputi : (1) harta kekayaan material, harta kekayaan inmateril,

${ }^{5}$ Ahmad M. Ramli, Hak atas Kepemilikan Intelektual : Teori Dasar Perlindungan Rahasia Dagang. Bandung : Mandar Maju, 2000, hal. 23. perikatan. Harta kekayaan material terdiri dari benda-benda tetap (tak bergerak) dan benda-benda lepas (bergerak)". ${ }^{6}$

Sedangkan

perikatan bersumber dari perjanjian dan undang-undang yang terdiri dari perbuatan yang dibenarkan dan perbuatan melanggar hukum. Harta kekayaan adalah segala sesuatu yang dapat memenuhi kebutuhan seseorang. Menurut Pipin Syarifin, Dedah Jubaedah, bila orang berkedudukan sebagai subjek hukum, maka harta kekayaan merupakan objek huku adalah :

"Harta kekayaan imaterial, misalnya saja ciptaan sebagai objek hak cipta dalam Hukum Perdata Internasional Inggris dianggap merupakan bagian dari pada benda-benda lepas (bergerak). Dengan demikian hukum yang dipergunakan adalah hukum yang berlaku bagi benda-benda bergerak". ${ }^{7}$

Dengan demikian hukum yang digunakan adalah hukum yang berlaku pada benda-benda bergerak. Istilah Property Rights diterjemahkan dengan istilah Hak atas Kekayaan Intelektual yang berarti suatu hak atas milik yang berada dalam ruang lingkup kehidupan teknologi, ilmu pengetahuan maupun seni dan sastra, pemilikannya bukan terhadap barangnya melainkan terhadap hasil kemampuan

${ }^{6}$ Subekti, Hukum Perdata, Jakarta : Intermasa, 2001, hal. 60. 2004, hal. 2 
intelektual manusianya, diantaranya berupa idea.

\section{Macam-macam Hak}

\section{Kekayaan Intelektual}

Pengaturan hak-hak yang timbul dari karya-karya intelektual menjadi sangat penting, bukan saja dari segi perlindungan hukum, akan tetapi karena peranannya dalam kehidupan perjanjianperjanjian internasional, perkembangan teknologi industri dan perdagangan yang semakin pesat. Sehingga dalam jangka waktu tertentu peraturan perundang-undangan bidang kekayaan intelektual tersebut sering mengalami perubahan atau diganti dengan undang-undang yang baru dan disesuaikan dengan perkembangan teknologi, industri dan perdagangan tersebut.

Hak atas Kekayaan Intelektual atas hak atas kepemilikan intelektual itu dapat berkembang, akan tetapi sementara yang telah dilindungi oleh hukum atau undang-undang, menurut Pipin Syarifin dan Dedah Jubaedah, ada 7 (tujuh) bidang sebagai berikut :

1. Bidang Perlindugnan Varietas Tanaman

2. Bidang Rahasia Dagang

3. Bidang Desain Industri

4. Bidang Desain Tata Letak Sirkuit Terpadu

5. Bidang Paten

6. Bidang Merek

7. Bidang Hak Cipta. ${ }^{8}$
Ketujuh bidang ini merupakan bagian dari sistem hukum Hak Kekayaan Intelektual.

\section{B. Merek}

\section{Pengertian Merek}

Dalam Pasal 1angka 1 UndangUndang Nomor 15 Tahun 2001 tentang Merek diberikan suatu pengertian tentang merek yaitu :

"Merek adalah tanda yang berupa gambar, nama, kata, hurufhuruf, angka-angka, susunan warna, atau kombinasi dari unsurunsur tersebut yang memiliki daya pembeda dan digunakan dalam kegiatan perdagangan barang atau jasa". ${ }^{9}$

Selain menurut batasan yuridis beberapa sarjana juga memberikan pendapat tentang merek yaitu :

H.M.N. Purwo Sutjipto dikutip oleh OK. Saidin memberikan rumusan bahwa : "Merek adalah suatu tanda, dengan mana suatu benda tertentu dipribadikan, sehingga dapat dibedakan dengan benda lain yang sejenis". ${ }^{10}$

Dari definisi tersebut, maupun dari peraturan tentang merek, secara umum terlihat bahwa yang diartikan dengan perkataan merek adalah suatu tanda (sign) untuk membedakan barang-barang atau jasa yang sejenis yang dihasilkan atau diperdagangkan seseorang atau kelompok orang atau badan hukum dengan barang-barang atau jasa yang sejenis yang dihasilkan

${ }^{9}$ Undang-Undang tentang Merek, UU Nomor 15 Tahun 2001, Op.cit. Pasal 1 angka 1. ${ }^{10}$ OK. Saidin, Op.cit., hal. 343. 
oleh orang lain, yang memiliki daya pembeda maupun sebagai jaminan atas mutunya dan digunakan dalam kegiatan perdagangan barang atau jasa.

\section{Dasar Hukum Merek}

Berdasarkan uraian tersebut di atas, Pipin Syarifin, Dedah jubaedah menyimpulkan bahwa, peraturan merek yang pernah berlaku di Indonesia sebagai berikut :

a. Undang - Undang Merek Kolonial Tahun 1912

b. Undang-Undang Republik Indonesia Nomor 21 Tahun 1961 tentang Merek Perusahaan dan Merek Perniagaan.

c. Undang-Undang Republik Indonesia Nomor 19 Tahun 1992 tentang Merek.

d. Undang-Undang Republik Indonesia Nomor 14 Tahun 1997 tentang Merek

e. Undang-Undang Republik Indonesia Nomor 15 Tahun 2001 tentang Merek. ${ }^{11}$

Dalam Undang - Undang Indonesia Nomor 15 Tahun 2001 tentang Merek ada ketentuan tentang istilah merek yang sudah terkenal (Pasal 6 ayat (1) huruf $b$. Dalam penjelasan Undang-undang tersebut diuraikan bahwa merek terkenal untuk barang dan jasa yang sejenis dilakukan dengan memperhatikan pengetahuan umum masyarakat mengenai hal. 164.

\footnotetext{
${ }^{11}$ Pipin Syarifin, Dedah Jubaedah, Op.cit.,
}

merek tersebut. Disamping itu diperhatikan pula reputasi merek terkenal yang diperoleh karena promosi yang gencar dan besarbesaran, investasi di beberapa negara di dunia yang dilakukan oleh pemiliknya dan disertai bukti pendaftaran merek tersebut di beberapa negara.

\section{Jenis Merek}

Dalam Undang - Undang Nomor 15 Tahun 2001 tentang Merek dijelaskan tentang jenis-jenis merek yaitu sebagaimana tercantum dalam Pasal 1 angka 2, 3 angka 4 Undang-Undang Nomot 15 Tahun 2001 tentang Merek mengenai merek dagang dan merek jasa yaitu :

a. Merek dagang adalah merek yang digunakan pada barang yang diperdagangkan oleh seseorang atau beberapa orang secara bersama-sama atau badan hukum untuk membedakan dengan barangbarang sejenis lainnya.

b. Merek Jasa adalah merek yang digunakan pada jasa yang diperdagangkan oleh seseorang atau beberapa orang secara bersama-sama atau badan hukum untuk membedakan dengan jasa-jasa sejenis lainnya.

c. Merek Kolektif adalah Merek yang digunakan pada barang dan / atau jasa dengan karakteristik yang sama yang diperdagangkan oleh beberapa orang atau badan hukum secara bersama - sama untuk 
membedakan dengan barang dan/atau jasa sejenis lainnya. ${ }^{12}$

Khusus untuk merek kolektif sebenarnya tidak dapat dikatakan sebagai jenis merek yang baru oleh karena merek kolektif ini sebenarnya juga terdiri dari merek dagang dan jasa. Hanya saja merek kolektif ini pemakaiannya digunakan secara kolektif.

\section{Persyaratan Merek}

Sebuah merek dapat disebut merek bila memenuhi syarat mutlak berupa adanya daya pembeda yang cukup (capable of distinguishing). Maksudnya tanda yang dipakai (sign) mempunyai kekuatan untuk membedakan barang atau jasa yang diproduksi sesuatu perusahaan dari perusahaan lainnya. Untuk mempunyai daya pembeda ini, maka merek itu harus dapat memberikan penentuan atau individualisering pada barang atau jasa bersangkutan.

Syarat mutlak suatu merek yang harus dipenuhi oleh setiap orang ataupun badan hukum yang ingin memakai suatu merek, agar supaya merek itu dapat diterima dan dipakai sebagai merek atau cap dagang, syarat mutlak yang harus dipenuhi adalah bahwa merek itu harus mempunyai daya pembeda yang cukup. Dengan lain perkataan, tanda yang dipakai ini haruslah sedemikian rupa, sehingga mempunyai cukup

${ }^{12}$ Undang-Undang Republik Indonesia Nomor 15 Tahun 2001, Op.cit., Pasal 1 angka 2, 3, dan 4 . kekuatan untuk membedakan barang hasil produksi sesuatu perusahaan atau barang perniagaan (perdagangan) atau jasa dari produksi seseorang dengan barangbarang atau jasa yang diproduksi oleh orang lain.

Penggunaan sesuatu merek dalam praktek juga membawa pengaruh. Jika suatu merek sudah cukup dikenal dalam masyarakat, maka merek tersebut dianggap telah mempunyai daya pembeda hal ini sesuai dengan ketentuan Pasal 1 angka 1 Undang-Undang Nomor 15 Tahun 2001 tentang Merek, yang cukup hingga diterima sebagai merek terkenal.

\section{Pembatalan Merek}

Pendaftaran merek hanya dapat dimintakan pembatalannya oleh pihak yang berkepentingan, yaitu antara lain : jaksa, yayasan atau lembaga di bidang konsumen, dan majelis lembaga keagamaan. Mereka dapat mengajukan gugatan pembatalan merek dengan alasan sebagaimana diatur dalam Undang - Undang Nomor 15 Tahun 2001 tentang Merek, Pasal 4, Pasal 5 dan Pasal 6 .

\section{HUKUM PERJANJIAN LISENSI MEREK}

\section{A. Hukum Perjanjian}

\section{Pengertian Perjanjian}

Manusia merupakan mahluk sosial, yaitu mahluk yang membutuhkan interaksi dengan manusia lainnya. Interaksi antar 
umat manusia tersebut tidak hanya komunikasi saja tetapi juga menyangkut seluruh aspek kehidupan, tidak terkecuali aspek hukum. Hubungan hukum secara perorangan antar manusia, tergolong dalam hukum perdata. Dalam hukum perdata mencakup banyak bidang, salah satunya dalam hubungan perjanjian yang pada dasarnya diciptakan sesama manusia untuk mempertegas hubungan antara mereka.

Menurut Subekti mengenai perjanjian menegaskan bahwa : "Suatu perjanjian adalah suatu peristiwa dimana seseorang berjanji kepada orang lain atau dimana dua orang berjanji kepada orang lain atau dimana dua orang berjanji untuk melaksanakan suatu hal". ${ }^{13}$

\section{Syarat Sahnya Perjanjian}

Pasal 1320 KUHPerdata menyatakan bahwa untuk sahnya suatu perjanjian diperlukan empat syarat, yaitu:

a. kesepakatan mereka yang mengikatkan dirinya;

b. kecakapan untuk membuat sesuatu perikatan;

c. suatu hal tertentu;

d. suatu sebab yang tidak terhalang (halal). ${ }^{14}$

\section{Asas-asas Hukum Perjanjian}

Asas - asas hukum yang penting diperhatikan pada waktu membuat perjanjian maupun melaksanakannya sebagai berikut :

${ }^{13}$ Subekti, Hukum Perjanjian, Jakarta : PT Intermasa, 2002, hal. 1. Pasal 1320 a. Asas Konsensualisme (Asas Kekuasaan Bersepakat) Asas konsensualisme (contract vrijheld) disebutkan pada Pasal 1458 KUHPerdata

b. Asas Kekuatan Mengikat dari Perjanjian Asas kekuatan mengikat dari perjanjian artinya, pihak-pihak harus memenuhi apa yang telah dijanjikan sebagaimana disebutkan dalam Pasal 1338 KUHPerdata, bahwa perjanjian berlaku sebagai undang-undang bagi para pihak yang membuatnya.

c. Asas Kebebasan Berkontrak. Asas kebebasan berkontrak maksudnya bahwa setiap orang boleh mengadakan perjanjian apa saja dan dengan siapa saja. Ketentuan tentang azas ini disebutkan di dalam Pasal 1338 KUHPerdata.

d. Asas Tidak Boleh Main Hakim Sendiri. Apabila dalam suatu perjanjian, baik itu perjanjian jual beli maupun perjanjianperjanjian lainnya, telah tercapai kata sepakat antara kedua belah pihak, dan kemudian ternyata tidak bisa dipenuhi oleh salah satu pihak yang seharusnya berkewajiban untuk melaksanakan perjanjian sebagaimana yang telah disepakati, maka dengan sendirinya pihak yang melakukan wanprestasi bisa dipaksa untuk memenuhi kewajibannya.

e. Asas Obligator Suatu Kontrak. Menurut hukum kontrak, suatu kontrak bersifat obligator, maksudnya adalah setelah sahnya suatu kontrak, maka 
kontrak tersebut sudah mengikat, tetapi baru sebatas menimbulkan hak dan kewajiban di antara para pihak. Tetapi pada taraf tersebut hak milik belum berpindah ke pihak lain. Untuk dapat memindahkan hak milik, diperlukan kontrak lain yang disebut dengan kontrak kebendaan (zakelijke overeenkomst). Perjanjian kebendaan inilah yang sering disebut dengan penyerahan (levering).

\section{B. Lisensi Merek}

Pemilik merek terdaftar berhak memberikan lisensi kepada pihak lain dengan perjanjian dan wajib dicatatkan ke Direktorat Jenderal Hak Kekayaan Intelektual, di mana pemilik merek masih tetap berhak menggunakannya dan memberikan lisensi kepada pihak lainnya. Perjanjian lisensi dilarang memuat ketentuan yang dapat merugikan perekonomian Indonesia baik secara langsung maupun tidak langsung dan memuat pembatasan yang menghambat kemampuan bangsa Indonesia dalam menguasai dan mengembangkan teknologi pada umumnya. Direktorat Jenderal Hak Kekayaan Intelektual berhak menolak permohonan pencatatan apabila memuat larangan tersebut, dan yang paling penting adalah pemilik merek terdaftar terhadap royalitynya.

Menurut Muhamad Djumhana dan R. Djubaedillah menyebutkan bahwa:

"Merek sebagai hak milik dapat dialih tangankan, baik melalui pewarisan hibah, wasiat, maupun dengan cara perjanjian dalam bentuk akta notaris, atau sebab-sebab lain yang dibenarkan oleh undang-undang. Pengalihan merek dapat dilakukan kepada perorangan maupun kepada badan hukum. Segala bentuk pengalihan ini wajib didaftarkan untuk dicatat dalam Daftar Umum Merek". ${ }^{15}$

Pengalihan hak mempunyai kekuatan terhadap pihak ketiga hanya bila telah tercatat dalam Daftar Umum Merek, memurut Sudargo Gautama, "Sistem pencatatan tersebut sebagai suatu yang mutlak untuk mempunyai kekuatan hukum terhadap pihak ketiga, dan dengan demikian seolah-olah mempunyai kekuatan yang dianggap dalam hukum bersifat $z$ akelijk". ${ }^{16}$

Dalam ketentuan Pasal 1 angka 13 Undang-Undang Nomor 15 Tahun 2001 tentang Merek, merumuskan bahwa :

"Lisensi adalah izin yang diberikan oleh pemilik Merek terdaftar kepada pihak lain melalui suatu perjanjian berdasarkan pada pemberian hak (bukan pengalihan hak) untuk menggunakan Merek tersebut, baik untuk seluruh atau sebagian jenis barang dan/atau jasa yang didaftarkan dalam jangka waktu dan syarat tertentu". ${ }^{17}$

Selain melalui bentuk pengalihan merek, seseorang atau badan hukum dapat menggunakan merek tertentu

${ }^{15}$ Muhamad Djumhana dan Djubaedillah, Op.cit., hal. 179-180.

${ }^{16}$ Sudargo Gautama, Hukum Merek Indonesia, Bandung : Alumni, 1977, hal. 61.

${ }^{17}$ Undang-Undang Republik Indonesia Nomor 15 Tahun 2001, Op.cit., Pasal 1 angka 13. 
dengan melalui cara lisensi merek. Ketentuan-ketentuan tentang kontrak lisensi merek dalam Undang-Undang Nomor 15 Tahun 2001 tentang Merek terdapat dalam ketentuan Pasal 43 sampai dengan Pasal 49.

Pasal 43 Undang-Undang Nomor 15 Tahun 2001 tentang Merek, merumuskan bahwa :

(1) Pemilik Merek terdaftar berhak memberikan Lisensi kepada pihak lain dengan perjanjian bahwa penerima Lisensi akan menggunakan Merek tersebut untuk sebagian atau seluruh jenis barang atau jasa.

(2) Perjanjian Lisensi berlaku di seluruh wilayah Negara Republik Indonesia, kecuali bila diperjanjikan lain, untuk jangka waktu yang tidak lebih lama dari jangka waktu perlindungan Merek terdaftar yang bersangkutan.

(3) Perjanjian Lisensi wajib dimohonkan pencatatannya pada Direktorat Jenderal dengan dikenai biaya dan akibat hukum dari pencatatan perjanjian Lisensi berlaku terhadap pihak-pihak yang bersangkutan dan terhadap pihak ketiga.

(4) Perjanjian Lisensi sebagaimana dimaksud pada ayat (3) dicatat oleh Direktorat Jenderal dalam Daftar Umum Merek dan diumumkan dalam Berita Resmi Merek. ${ }^{18}$

Pemberian lisensi kepada pihak lain, harus ditaungkan dalam bentuk perjanjian lisensi, dan setiap pelepasan hak perjanjian (termasuk perjanjian lisensi) harus dituangkan dalam bentuk akta perjanjian. Jadi tidak boleh dilakukan secara lisan.

Pasal 44 Undang-Undang Nomor 15 Tahun 2001 tentang Merek, merumuskan bahwa :

"Pemilik Merek terdaftar yang telah memberikan Lisensi kepada pihak lain sebagaimana dimaksud dalam Pasal 43 ayat (1) tetap dapat menggunakan sendiri atau memberikan Lisensi kepada pihak ketiga lainnya untuk menggunakan Merek tersebut, kecuali bila diperjanjikan lain". ${ }^{19}$

Dari ketentuan Undang-Undang Nomor 15 Tahun 2001 tentang Merek, dapat disimpulkan memuat ketentuan sebagai berikut :

a. Lisensi merek dapat dilakukan, baik untuk sebagian atau seluruh jenis barang atau jasa.

b. Perjanjian lisensi berlaku di seluruh wilayah Indonesia, kecuali diperjanjikan lain, untuk jangka waktu yang tidak lebih lama dari jangka waktu perlindungan Merek terdaftar yang bersangkutan.

c. Perjanjian lisensi wajib dimohonkan pencatatannya dalam daftar umum merek dan diumumkan dalam Berita Resmi Merek.

d. Pemilik merek yang memberikan lisensi, tetap dapat menggunakan sendiri atau memberi lisensi kepada pihak ketiga lainnya untuk

${ }^{18}$ Ibid., Pasal 43

${ }^{19}$ Ibid., Pasal 44 
menggunakan merek tersebut, kecuali bila diperjanjikan lain.

e. Pihak si penerima lisensi dapat juga ditentukan bahwa mereka dapat memberi lisensi lebih lanjut kepada pihak lainnya, ketentuan ini tidak menghilangkan kewajiban penerima lisensi untuk menggunakan sendiri merek tersebut dalam perdagangan.

Ketentuan di atas merupakan ketentuan yang paling mendasar dari suatu pengaturan mengenai lisensi merek.

\section{ANALISIS YURIDIS SENGKETA PERJANJIAN LISENSI MEREK}

\section{A. Dasar Pelaksanaan Pengelolaan Administrasi Merek}

Penyelenggaraan administrasi oleh Direktorat Jenderal Hak Atas Kekayaan Intelektual, masih harus pula memperhatikan kewenangan instansi lain, sesuai dengan perundang-undangan. Dalam melaksanakan pengelolaan merek Direktorat Jenderal Hak Atas Kekayaan Intelektual memperoleh pembinaan dan bertanggungjawab kepada Menteri Kehakiman.

1. Sistem Pendaftaran Merek

Dalam pendaftaran merek, saat ini dikenal 2 (dua) macam sistem pendaftaran yaitu :

a. Sistem deklaratif

Sistem deklaratif (pasif) mengandung pengertian bahwa pendaftaran itu bukanlah menerbitkan hak, melainkan hanya memberikan dugaan, atau sangkaan hukum (rechtsvermoeden), atau presemption iuris, yaitu bahwa pihak yang mereknya terdaftar itu adalah pihak yang berhak atas merek tersebut dan sebagai pemakai permata dari merek yang didaftarkan.

Dalam sistem pasif, pada saat pendaftaran tidak diselidiki siapa yang benar-benar merupakan pemilik asli merek yang bersangkutan dan tidak diadakan pengumuman terlebih dahulu untuk memberitahukan pada khalayak umum tentang adanya pihak yang mendaftarkan suatu merek tertentu. Dengan demikian, tidak adanya kesempatan pihak lain untuk menyanggah yang mendaftarkan mereknya.

b. Sistem konstitutif

Sistem konstitutif mempunyai kelebihan dalam soal kepasitan hukumnya. Sistem konstitutif (aktif) dengan dokrinya "prior in filing", bahwa yang berhak atas suatu merek adalah pihak yang telah mendaftarkan mereknya dikenal dengan asas presumption of ownership. Jadi, pendaftaran itu menciptakan suatu hak atas merek tersebut, pihak yang mendaftarkan dialah satusatuanya yang berhak atas suatu merek dan pihak ketiga harus menghormati haknya pendaftar merek sebagai hak mutlak. 
2. Prosedur Permohonan Pendaftaran Merek

Prosedur permohonan merek di Indonesia telah diatur dalam ketentuan Peraturan Pemerintah Nomor 23 Tahun 1993 tentang Tata Cara Permohonan Pendaftaran Merek. Permohonan pendaftaran merek diajukan tertulis kepada Direktorat Jenderal Hak Atas Kekayaan Intelektual. Surat Permohonan Pendaftaran Merek tersebut harus diajukan dalam bahasa Indonesia kepada Direktorat Jenderal Hak Atas Kekayaan Intelektual, dengan dilengkapi :

a. Surat pernyataan bahwa merek yang dimintakan pendaftaran adalah miliknya.

b. Dua puluh helai etiket merek yang bersangkutan.

c. Tambahan Berita Negara yang memuat akta pendirian badan hukum atau salinan yang sah akta pendirian badan hukum apabila pemilik merek adalah badan hukum Indonesial.

d. Surat kuasa khusus apabila permohonan pendaftaran merek diajukan melalui kuasa.

e. Pembayaran biaya yang telah ditentukan.

f. Salinan peraturan penggunaan merek kolektif, apabila permohonan pendaftaran merek akan digunakan sebagai merek kolektif.

Apabila peraturan penggunaan merek kolektif tersebut tidak menggunakan bahasa Indonesia, maka harus disertai terjemahannya dalam bahasa Indonesia.

3. Pemeriksaan Pendaftaran Merek

Direktorat Jenderal Hak Atas Kekayaan Intelektual sebelum memutuskan menerima permohonan pendaftaran merek, terlebih dahulu melakukan pemeriksaan terhadap kelengkapan persyaratan pendaftaran. Jika terdapat kekurang lengkapan persyaratannya, maka kekuranganya harus dipenuhi dalam waktu selambat-lambatnya 2 (dua) bulan sejak penerimaan surat dari Direktorat Jenderal Hak Atas Kekayaan Intelektual yang memerintahkan pemohon untuk melengkapi kekurangannya. Apabila kekurang lengkapan syarat pendaftaran tersebut dimohonkan dengan hak prioritas, maka jangka waktu pemenuhan kekurangannya tersebut selambat-lambatnya 3 (tiga) bulan sejak tanggal berakhirnya jangka waktu pengajuan permohonan pendaftaran merek dengan hak prioritas.

4. Penghapusan dan Pembatalan Pendaftaran Merek.

Penghapusan pendaftaran merek dari Daftar Umum Merek dapat dilakukan dan Direktorat Jenderal Hak Atas Kekayaan Intelektual, baik atas prakarsa sendiri maupun berdasarkan permohonan pemilik merek yang bersangkutan.

Ketentuan penghapusan atas prakarsa Direktorat Jenderal Hak Atas Kekayaan Intelektual dalam 
pengaturan Pasal 61 ayat (2) Undang-Undang Nomor 15 Tahun 2001 tentang Merek.

5. Ketentuan Khusus Pendaftaran Merek Terkenal

Permohonan pendaftaran merek dalam Daftar Umum ditolak apabila merek yang didaftarkan adalah:

a. Merek terkenal milik orang lain atau merek badan lain.

b. Merek yang mempunyai persamaan atau kemiripan, baik pada pokoknya maupun pada keseluruhannya dengan merek terkenal milik orang lain atau milik badan lain.

Ketentuan yang mendasari
Surat Keputusan
Kehakiman ini adalah bahwa
Menteri Kehakiman sebagai
pejabat yang membawahi
administrasi Paten, Merek dan Hak
Cipta, mempunyai kewenangan
secara ex officio melakukan
pembatalan.

6. Hak Prioritas

Setiap orang yang telah mengajukan aplikasi permohonan suatu hak kepada suatu negara dari peserta Uni akan memperoleh hak prioritas untuk mengajukan pendaftaran di lain negara. Di Indonesia ketentuan ini tercantum dalam Pasal 11 dan Pasal 12 Undang-Undang Nomor 15 Tahun 2001 tentang Merek.

Permohonan pendaftaran merek dengan menggunakan hak prioritas wajib dilengkapi dengan bukti penerimaan permohonan pendaftaran yang pertama kali yang menimbulkan hak prioritas tersebut. Bukti tersebut berupa surat permohonan pendaftaran merek beserta tanda penerima permohonan tersebut yang juga memberikan penegasan tentang tanggal penerimaan permohonan pendaftaran merek.

\section{B. Faktor Penyebab Terjadinya Sengketa Dalam Perjanjian Lisensi Merek}

Persoalan-persoalan tersebut maka secara umum ada beberapa faktor yang sering terjadinya sengketa dalam perjanjian lisensi merek dengan caracara adalah sebagai berikut :

\section{Praktik Peniruan Merek Dagang}

Pengusaha yang beriktikad tidak baik tersebut dalam hal persaingan tidak jujur semacam ini berwujud penggunaan upayaupaya atau ikhtiar-ikhtiar mempergunakan merek dengan meniru merek terkenal (well know trade mark) yang sudah ada sehingga merek atas barang atau jasa yang diproduksinya secara pokoknya sama dengan merek atas barang atau jasa yang sudah terkenal (untuk barang-barang atau jasa sejenis) dengan maksud menimbulkan kesan kepada khalayak ramai, seakan-akan barang atau jasa yang diproduksinya itu sama dengan produksi barang atau jasa yang sudah terkenal itu. Dalam hal ini dapat diberikan contoh, bahwa dalam masyarakat sudah dikenal dengan baik sabun mandi dengan 
merek "Lux" kemudian ada pengusaha yang memproduksi sabun mandi merek "Lax". Tentunya pengusaha ini berharap bahwa dengan adanya kemiripan tersebut ia dapat memperoleh keuntungan yang besar tanpa mengeluarkan biaya besar untuk promosi memperkenalkan produksinya tersebut. Hal ini karena konsumen dapat dikelabui dengan kemiripan merek tersebut.

2. Praktik Pemalsuan Merek Dagang

Dalam hal ini persaingan tidak jujur tersebut dilakukan oleh pengusaha yang tidak beriktikad baik itu dengan cara memproduksi barang-barang dengan mempergunakan merek yang sudah dikenal secara luas di dalam masyarakat yang bukan merupakan haknya. Sebagai contoh seorang pengusaha yang sedang berbelanja ke luar negeri membeli produk Cartier, kemudian kembali ke Indonesia untuk memproduksi barang-barang tas dan dompet yang diberi merek Cartier.

Dalam hal ini juga maka pengusaha itu tentunya sangat berharap memperoleh keuntungan besar tanpa mengeluarkan biaya untuk memperkenalkan merek tersebut kepada masyarakat karena merek tersebut sudah dikenal oleh masyarakat dan tampaknya pemakaian kata Cartier itu merupakan kekuatan simbolik yang memberikan kesan mewah dan bergengsi, sehingga banyak konsumen membelinya.
3. Perbuatan-perbuatan yang Dapat Mengacaukan Publik Berkenaan Dengan Sifat dan Asal Usul Merek

Hal ini terjadi karena adanya tempat atau daerah suatu negara yang dapat menjadi kekuatan yang memberikan pengaruh baik pada suatu barang karena dianggap sebagai daerah penghasil jenis barang yang bermutu. Termasuk dalam persaingan tidak jujur apabila pengusaha mencantumkan keterangan tentang sifat dan asal-usul barang yang tidak sebenamya, untuk mengelabui konsumen, seakanakan barang tersebut memiliki kualitas yang baik karena berasal dari daerah penghasil barang yang bermutu misalnya mencantumkan keterangan made in England padahal tidak benar produk itu berasal dari Inggris.

Seluruh perbuatan itu sangat merugikan pemilik merek. Karena akibat dari persaingan tidak jujur (pemalsuan dan peniruan merek terkenal) akan mengurangi omzet penjualan sehingga mengurangi keuntungan yang sangat diharapkan dari mereknya yang lebih terkenal tersebut. Bahkan dapat menurunkan kepercayaan masyarakat terhadap merek tersebut, karena konsumen menganggap bahwa merek yang dulu dipercaya memiliki mutu yang baik ternyata sudah mulai turun kualitasnya.

Bukan hanya itu saja, pelanggaran terhadap hak atas merek ini juga sangat merugikan konsumen karena konsumen akan 
memperoleh barang-barang atau jasa yang biasanya mutunya lebih rendah dibandingkan dengan merek asli yang sudah terkenal tersebut, bahkan adakalanya produksi palsu tersebut membahayakan kesehatan dan jiwa konsumen. Mengapa timbul praktek yang demikian itu, tentu tidak lain terbit juga dengan adanya fungsi merek itu sendiri.

\section{Upaya Penyelesaian Perselisihan Terhadap Pelanggaran Merek}

Upaya hukum yang dapat dilakukan salah satu pihak apabila merasa dirugikan dengan adanya perjanjian lisensi merek diantaranya dengan penyelesaian sengketa alternatif yang diatur dalam Pasal 84 Undang-Undang Nomor 15 Tahun 2001 tentang Merek yang menyebutkan para pihak dapat menyelesaikan sengketa melalui arbitrase atau alternatif penyelesaian sengketa. Selain dalam UndangUndang Merek penyelesaian sengketa alternatif lebih khusus diatur dalam Undang-Undang Nomor 30 Tahun 1999 tentang Arbitrase dan Alternatif Penyelesaian Sengketa Alternatif.

Penyelesaian Sengketa dalam ruang lingkup hukum keperdataan khususnya Perjanjian Lisensi Merek dapat diselesaikan secara non litigasi yaitu penyelesaian sengketa alternatif diluar sistem dan hukum acara yang berlaku pada badan peradilan. Alternatif penyelesaian sengketa dapat diselesaikan dengan konsultasi, negosiasi, mediasi, konsiliasi, atau penilaian ahli serta melalui arbitrase. Kemudian dapat secara litigasi diselesaikan melalui badan pengadilan dengan mempergunakan hukum acara perdata yang berlaku di Indonesia sebagaimana diatur di dalam UndangUndang Nomor 15 Tahun 2001 dapat diajukan kepada Pengadilan Niaga maupun Pengadilan Negeri (diatur dalam Pasal 90 Undang-Undang Nomor 15 Tahun 2001). ${ }^{20}$

Sanksi yang diberikan kepada tergugat dapat berupa ganti rugi dalam sejumlah uang, penghentian semua perbuatan yang berkaitan dengan menggunakan merek tersebut, serta pidana dan denda yang diterapkan bersamaan, hal ini tergantung dari tingkat kesalahan dari pelanggar itu sendiri.

Upaya hukum bagi pelanggaran merek dagang, dengan mengacu pada ketentuan Undang-Undang Nomor 15 Tahun 2001 tentang Merek terdapat pada Pasal 76 dan mengapa tuntutan sebagaimana tercantum dalam Pasal 76 Undang-Undang Nomor 15 Tahun 2001 tentang Merek, dikategorikan perbuatan melawan hukum dan tuntutan yang didasarkan pada Pasal 77 dan Pasal 78 Undang-Undang Nomor 15 Tahun 2001 tentang Merek sepanjang mengenai kewajiban pemegang lisensi dikategorikan dalam peristiwa wan prestasi, alasannya adalah peristiwa yang diatur dalam Pasal 76 Undang-Undang Nomor 15 Tahun 2001 tentang Merek, lahirnya hak dan kewajiban didasarkan atas undang-undang, tidak dengan perjanjian. Sedangkan peristiwa yang diatur dalam Pasal 77 dan Pasal 78 Undang-Undang Nomor 15 Tahun 2001 tentang Merek lahirnya hak dan

\footnotetext{
${ }^{20}$ Erman Rajagukguk, Arbitrase Dalam Putusan Pengadilan, Chandra Pertama, Jakarta, 2000, hal.1.
} 
kewajiban atas dasar suatu perjanjian (lisensi).

Oleh karena itu sepanjang mengenai tuntutan ganti rugi yang didasarkan kepada kedua peristiwa di atas berlaku pula ketentuan yang termuat dalam KUHPerdata yang disebut berfungsi sebagai Lex Generalis, sedangkan Undang-Undang Nomor 15 Tahun 2001 tentang Merek sendiri berfungsi sebagai Lex Specialis.

\section{PENUTUP}

\section{A. Kesimpulan}

Kesimpulan yang dapat penulis sampaikan adalah sebagai berikut:

1. Administrasi merek mengurus masalah yang berkaitan dengan tata cara, dan penatausahaan merek. Dalam melaksanakan pengelolaan merek Direktorat Jenderal Hak Atas Kekayaan Intelektual memperoleh pembinaan dan bertanggungjawab kepada Menteri Kehakiman.

a. Sistem Pendaftaran Merek, dalam pendaftaran merek, saat ini dikenal 2 (dua) macam sistem pendaftaran yaitu : Sistem deklaratif dan Sistem konstitutif.

b. Prosedur Permohonan Pendaftaran Merek yaitu prosedur permohonan merek di Indonesia telah diatur dalam ketentuan Peraturan Pemerintah Nomor 23 Tahun 1993 tentang Tata Cara Permohonan Pendaftaran Merek. c. Pemeriksaan Pendaftaran Merek, dimana Direktorat Jenderal sebelum memutuskan menerima permohonan pendaftaran merek, terlebih dahulu melakukan pemeriksaan terhadap kelengkapan persyaratan pendaftaran. Jika terdapat kekurang lengkapan persyaratannya, maka kekuranganyna harus dipenuhi dalam waktu selambatlambatnya 2 (dua) bulan sejak penerimaan surat dari Direktorat Jenderal Hak Atas Kekayaan Intelektual yang memerintahkan pemohon untuk melengkapi kekurangannya. Apabila kekuranglengkapan syarat pendaftaran tersebut dimohonkan dengan hak prioritas, maka jangka waktu pemenuhan kekurangannya tersebut selambat-lambatnya 3 (tiga) bulan sejak tanggal berakhirnya jangka waktu pengajuan permohonan pendaftaran merek dengan hak prioritas.

d. Penghapusan dan Pembatalan Pendaftaran Merek

Penghapusan pendaftaran merek dari Daftar Umum Merek dapat dilakukan dan Direktorat Jenderal Hak Atas Kekayaan Intelektual, baik atas prakarsa sendiri maupun berdasarkan permohonan pemilik merek yang bersangkutan. Ketentuan penghapusan atas prakarsa Direktorat Jenderal Hak Atas 
Kekayaan Intelektual dalam pengaturan Pasal 61 ayat (2) Undang-Undang Nomor 15

Tahun 2001 tentang Merek.

e. Ketentuan Khusus

Pendaftaran Merek Terkenal

Permohonan pendaftaran merek dalam Daftar Umum ditolak apabila merek yang didaftarkan adalah :

1) Merek terkenal milik orang lain atau merek badan lain.

2) Merek yang mempunyai persamaan atau kemiripan, baik pada pokoknya maupun pada keseluruhannya dengan merek terkenal milik orang lain atau milik badan lain.

\section{f. Hak Prioritas}

Setiap orang yang telah mengajukan aplikasi permohonan suatu hak kepada suatu negara dari peserta Uni akan memperoleh hak prioritas untuk mengajukan pendaftaran di lain negara. Di Indonesia ketentuan ini tercantum dalam Pasal 11 dan Pasal 12 Undang-Undang Nomor 15 Tahun 2001 tentang Merek

2. Faktor penyebab terjadinya sengketa dalam perjanjian lisensi merek dengan cara-cara adalah sebagai berikut :

a. Praktik Peniruan Merek Dagang yaitu pengusaha yang beriktikad tidak baik tersebut dalam hal persaingan tidak jujur semacam ini berwujud penggunaan upaya-upaya atau ikhtiar-ikhtiar mempergunakan merek dengan meniru merek terkenal (well know trade mark) yang sudah ada sehingga merek atas barang atau jasa yang diproduksinya secara pokoknya sama dengan merek atas barang atau jasa yang sudah terkenal (untuk barang-barang atau jasa sejenis) dengan maksud menimbulkan kesan kepada khalayak ramai, seakan-akan barang atau jasa yang diproduksinya itu sama dengan produksi barang atau jasa yang sudah terkenal itu.

b. Praktik Pemalsuan Merek Dagang

Dalam hal ini persaingan tidak jujur tersebut dilakukan oleh pengusaha yang tidak beriktikad baik itu dengan cara memproduksi barangbarang dengan mempergunakan merek yang sudah dikenal secara luas di dalam masyarakat yang bukan merupakan haknya.

c. Perbuatan-perbuatan yang Dapat Mengacaukan Publik Berkenaan Dengan Sifat dan Asal Usul Merek

Hal ini terjadi karena adanya tempat atau daerah suatu negara yang dapat menjadi kekuatan yang memberikan 
pengaruh baik pada suatu barang karena dianggap sebagai daerah penghasil jenis barang yang bermutu. Termasuk dalam persaingan tidak jujur apabila pengusaha mencantumkan keterangan tentang sifat dan asal-usul barang yang tidak sebenamya, untuk mengelabui konsumen, seakan-akan barang tersebut memiliki kualitas yang baik karena berasal dari daerah penghasil barang yang bermutu misalnya mencantumkan keterangan made in England padahal tidak benar produk itu berasal dari Inggris.

3. Penyelesaian Sengketa dalam ruang lingkup hukum keperdataan khususnya Perjanjian Lisensi Merek dapat diselesaikan secara non litigasi yaitu penyelesaian sengketa alternatif diluar sistem dan hukum acara yang berlaku pada badan peradilan. Alternatif penyelesaian sengketa dapat diselesaikan dengan konsultasi, negosiasi, mediasi, konsiliasi, atau penilaian ahli serta melalui arbitrase. Kemudian dapat secara litigasi diselesaikan melalui badan pengadilan dengan mempergunakan hukum acara perdata yang berlaku di Indonesia sebagaimana diatur di dalam Undang-Undang Nomor 15 Tahun 2001 dapat diajukan kepada Pengadilan Niaga maupun Pengadilan Negeri (diatur dalam Pasal 90 Undang-Undang Nomor 15 Tahun 2001).
B. Saran

Saran yang dapat, dikemukaan dalam permasalahan pada penulisan skripsi ini adalah sebagai berikut :

1. Bagi pelaku bisnis dan pejabat terkait melakukan adminsitrasi merek harus sesuai dengan ketentuan perundang-undangan yang berlaku.

2. Bagi para pelaku bisnis, sebaiknya dalam menghadapi persaingan bisnis terutama mengenai merek dagang, harus bersaing secara jujur dalam arti tidak boleh menyamakan merek dagang pihak lain.

3. Bagi pejabat terkait, sebaiknya dalam menetapkan merek harus dilihat bahwa merek tersebut ada kesamaan atau tidak dengan merek yang sudah didaftar terlebih dahulu atau sesuai dengan ketentuan Pasal 4, Pasal 6 ayat (1) $a, b$, serta ayat (3) a UndangUndang Nomor 15 Tahun 2001 tentang Merek sehingga tidak terjadinya sengketa dalam linsensi merek.

\section{DAFTAR PUSTAKA}

\section{Buku-buku}

Gautama, Sudargo, Hukum Merek Indonesia, Bandung : Alumni, 1977.

M. RAmli, Ahmad, Hak atas Kepemilikan Intelektual : Teori Dasar Perlindungan Rahasia Dagang. Bandung : Mandar Maju, 2000 
Rajagukguk, Erman, Arbitrase Dalam Putusan Pengadilan, Chandra Pertama, Jakarta, 2000.

Saidin, Ok., Aspek Hukum Hak Kekayaan Intelektual (Intellectual Property Rights), Jakarta : RajaGrafindo Persada, 2013.

Subekti, Hukum Perdata, Jakarta :

Intermasa, 2001.

Subekti, Hukum Perjanjian, Jakarta : PT Intermasa, 2002.

Syarifin, Pipin dan Dedah Jubaedah, Peraturan Hak Kekayaan Intelektual di Indonesia, Bandung : Putaka Bani Quraisy, 2004.

\section{Undang-Undang}

Kitab Undang-Undang Hukum Perdata.

Undang-Undang Republik

Indonesia Nomor 15 Tahun 2001

tentang Merek 